\title{
Summer Diversity Program enhances female and underrepresented minority student academic performance and retention in the Drexel University College of Engineering
}

\section{Ms. Alistar Erickson-Ludwig, Drexel University (Eng.)}

Ms. Alistar Erickson-Ludwig serves as the STEM Program Coordinator in the College of Engineering at Drexel University. She focuses on outreach and education related programs for current undergraduates, k-12 students, and the community. She concentrates on the Greater Philadelphia Sea Perch Underwater Robotics Competition, Summer Diversity Program, Introduce a Girl to Engineering Day, and Engineering Projects in Community Service (EPICS) at Drexel, among others. In collaboration with other College of Engineering faculty and staff she co-teaches a sequence of classes for the Paul Peck Scholars Program. Alistar received her B.A. from Drew University and Master's from Duke University.

\section{Dr. Alisa Morss Clyne, Drexel University (Eng.)}

Alisa Morss Clyne is currently an Associate Professor of Mechanical Engineering, with a courtesy appointment in the School of Biomedical Engineering, Science, and Health Systems, at Drexel University in Philadelphia, PA. Dr. Clyne is director of the Vascular Kinetics Laboratory, which investigates integrated mechanical and biochemical interactions among cells and proteins of the cardiovascular system. She is particularly interested in how endothelial cell mechanotransduction changes in a diseased environment, and how fluid shear stress and substrate mechanics affect growth factor binding kinetics, transport, and signaling. Her laboratory also translates fundamental discoveries in these areas into novel therapeutics, including nanoparticle-based drug delivery and tissue engineering scaffolds. Dr. Clyne received her bachelor's degree in Mechanical Engineering from Stanford University in 1996. She worked as an engineer in the GE Aircraft Engines Technical Leadership Program for four years, concurrently earning her Master's degree in Mechanical Engineering from the University of Cincinnati. In 2006, she received her Doctorate in Medical and Mechanical Engineering from the Harvard-MIT Division of Health Sciences and Technology. Dr. Clyne received an NSF CAREER award in 2008 and an American Heart Association Scientist Development Grant in 2010. She received both research and educational funding from NSF, NIH, Department of Education, the Nanotechnology Institute, and the State of Pennsylvania. She is a member of ASEE, ASME, BMES, IEEE-EMBC, Sigma Xi, and SWE. Her teaching focuses on mechanical engineering applications in biological systems, and she founded several programs to increase diversity within engineering. 


\title{
Summer Diversity Program enhances female and underrepresented minority student academic performance and retention in the Drexel University College of Engineering
}

\begin{abstract}
Women and minority students are underrepresented in the science, technology, engineering and mathematics (STEM) fields. Summer bridge programs may be one way to target this population, and help to ensure academic success and retention in the college years. Over the past three years, the College of Engineering hosted a "pre-orientation" program for accepted incoming students. The program goal was to prepare female and underrepresented minority freshmen for life as engineering students at Drexel University. This program familiarized students with the engineering curriculum and prepared them to succeed in their freshman year through community building and social activities. Program participants showed significant positive outcomes following the program in areas such as problem solving and experimentation, communication, data interpretation and organizational skills. In addition program participant retention was significantly higher than students that did not participate in the program. The authors believe that bridge programs and in particular, the College of Engineering Summer Diversity Program provided incoming female and underrepresented minority freshmen with the academic and social foundation to help them succeed in their engineering education.
\end{abstract}

\section{Introduction}

\section{The Need for Increased Diversity in Science, Technology, Engineering and Mathematics}

To maintain the United States' global competitiveness in technology and innovation, we must educate a large, creative technology workforce. The underrepresentation of women and minorities in engineering presents a growing challenge to sustaining our technology leadership. Women comprise more than $50 \%$ of earned bachelor's degrees but only $20 \%$ of those earned in engineering. Underrepresented minorities make up 28\% of the population and are projected to grow to $45 \%$ of the population by 2050 . Yet African Americans and Hispanics earn only 3-4\% of engineering bachelor's degrees ${ }^{1}$. In addition, educating female and minority engineers is essential to economic prosperity within these populations. The science and engineering labor force has grown at an annual rate of $5.9 \%$ since 1950 , which is nearly five times the total workforce growth rate ${ }^{1}$. Workers in science and engineering fields earn more than double the median earnings of the total US workforce and have lower unemployment rates ${ }^{1}$. Therefore, increasing the number of women and underrepresented minorities in engineering will grow the US technology workforce while increasing earning potential in these populations.

\section{Challenges in Female and Minority Student Enrollment Persistence}

Representation of women and minorities in STEM fields has increased over the past few decades but gaps still remain. Since the number of women and minority students who choose to enroll in engineering programs is low, it is critical that those who choose engineering are given every possible opportunity to succeed. The reasons why women and minority student engineering enrollment is low are complex and discussed thoroughly in other work. Briefly, women may be 
discouraged from choosing engineering due to the perception that engineering is a male field or the cognitive differences exist between men and women ${ }^{2}$. These perceived gender differences can have a considerable weight on an individual's career or job aspirations ${ }^{3}$. Minorities, both male and female, are less likely to have taken advanced degree classes in high school, which puts them at a disadvantage for being accepted into an engineering major in college ${ }^{2}$.

Increasing their persistence throughout their engineering education could enhance the number of women and minorities in the engineering profession. Data from 2009 shows that $3.3 \%$ of female students intended to major in engineering yet only $1.4 \%$ persisted to earn a degree ${ }^{1}$. Underrepresented minority students, notably African Americans, are less likely to graduate in science and engineering fields compared to members of other racial groups ${ }^{4,5}$. In engineering, only $32 \%$ of African Americans who intended to major in engineering received a degree. Many minorities who leave engineering may not persist to any undergraduate degree. Among students who entered STEM undergraduate majors, 35.2\% of Black students and 31.6\% of Hispanic students left postsecondary education without any degree (STEM or otherwise) compared to $24.6 \%$ of Caucasian students ${ }^{6}$. Part of the racial disparity in STEM persistence may be linked to inequalities in primary and secondary education ${ }^{7}$, including K-12 teacher quality, curriculum, class size and school size ${ }^{8}$.

\section{Strategies for Success: Summer Bridge Programs}

Proactive university support and commitment can help women and minorities integrate and persist throughout their engineering education ${ }^{4,9}$. During the academic year, tutoring and study centers can improve student preparation, commitment, and engagement, which enhances retention and graduation rates ${ }^{5}$. Students also benefit greatly from combined academic and social integration $5,10,11$. Successful retention programs emphasize counseling resources, social support and community membership ${ }^{5,12}$. In addition, counselors who are of the same racial group of the minority students tend to reduce isolation for minority students who use social support and counseling services ${ }^{13}$.

Outside of the academic year, summer bridge programs address the challenging transition from high school to college ${ }^{4}$. Existing summer bridge programs provide academic support, mentorship and a sense of community to enhance student long term success in college and the engineering field. A five week long Georgia Tech summer bridge program focuses on math, science, and English coursework and includes an academic mentorship and social component. The National Science Foundation supported Louis Stokes Alliances for Minority Participation (LSAMP) Summer Scholars program at Oregon State is focused on increasing the underrepresented minority student retention rate in STEM related majors by creating a community of diversity. Purdue University runs a five week Academic Boot Camp Program through which multi-ethnic accepted students are exposed to coursework, lifestyle, and the pace of college life. Students take a variety of specially designed courses that aim to help students understand where their strengths and weakness lie and where they can receive academic help if needed.

Little data is available on student demographics or retention outcomes for summer bridge programs; however, a few studies do show improved retention for summer bridge participants. A study of 617 students who participated in the Georgia Tech summer bridge between 1990 and 
2000 found that underrepresented minority students who participated in the program were $19 \%$ more likely to graduate than their underrepresented minority peers who did not participate in the program ${ }^{5}$. African American, Hispanic, and Native American student who participated in Purdue's Academic Boot Camp showed higher retention rates and first semester grade point $\operatorname{averages}^{14}$.

\section{Institution Overview and Program Objective}

The College of Engineering is the largest college within Drexel University, a large urban University located in Philadelphia, Pennsylvania. The College of Engineering supports students in 5 engineering disciplines (Chemical and Biological Engineering; Civil, Architectural, and Environmental Engineering; Electrical and Computer Engineering; Materials Science and Engineering; Mechanical Engineering and Mechanics). In 2013 nearly 1100 students joined the College of Engineering Freshman class. Female students composed approximately $21 \%$ of the incoming class and approximately $9 \%$ of the incoming class was African American and Hispanic students (Table 1). The Summer Diversity program is the only program within the College of Engineering that specifically targets underrepresented minority students and women. The Summer Diversity Program objective is to provide support for women and underrepresented minority incoming freshmen, with the goal of increasing retention through their first year and persistence to graduation.

Table 1: Race and Ethnicity Distribution in the College of Engineering 2013 Incoming Freshman Class

\begin{tabular}{|l|r|}
\hline Race & Count \\
\hline American Indiana or Alaska Native & 2 \\
\hline Asian & 166 \\
\hline Black or African American & 48 \\
\hline Hispanic & 52 \\
\hline Native Hawaiian or Other Pacific Islander & 11 \\
\hline Nonresident Alien (International) & 196 \\
\hline Race and Ethnicity Unknown & 13 \\
\hline Two or More Races & 29 \\
\hline White & 580 \\
\hline Total & 1097 \\
\hline
\end{tabular}

\section{Summer Diversity Program Overview}

Low female and minority enrollment and persistence in science and engineering results from a combination of complex issues, including K-12 mathematics and science education, access and motivation, college affordability, and academic and social support ${ }^{15}$. Since the pipeline flow is low, it is crucial to ensure that those female and minority students who choose to pursue engineering degrees have the support and resources that they need to be successful. Over the past three years, Drexel University College of Engineering hosted a Summer Diversity Program for 
accepted incoming students. The goal of this program is to provide academic and social support to help women and minority students who choose to become engineers persist through their first year and beyond. The program originally was one week long; however the program was expanded to two weeks in the second year to include more core content and to accommodate student requests for a more relaxed schedule.

\section{Recruitment}

Since the Program is focused on diversity, women and underrepresented incoming freshmen students of all academic levels were invited independent of their academic preparation. The program director emailed all women and underrepresented minorities in the College of Engineering incoming freshman class in the late spring. 71, 147, and 196 students were invited to the program in 2011, 2012, and 2013 respectively. The variation in invited student numbers was due to the targeted majors and international student inclusion. International students were included in the 2013 cohort, since they appeared to benefit from extra academic preparation, confidence building and community engagement in a similar way to domestic students. Male students with weaker academic preparation were not included, since the University has existing programs for students with lower academic preparation. Asian American students were not invited to participate in the program because they are not unrepresented within the College of Engineering.

Students submitted an application with questions such as, "Why are you interested in engineering?", "What would you like to do in your engineering career?", and "What is the biggest challenge in the world today that engineers can help solve?" Students listed the biggest engineering challenges as creating more efficient transportation, upgrading infrastructure, and developing renewable energy. Additional questions asked about the students' perceived academic strengths, weaknesses, and apprehension about their freshman year. Students noted that they were good problem solvers, excelled at math and science, liked to use logic, and worked well with others. Weaknesses included language arts, reading and writing, and maintaining a good balance. Students were also required to pay $\$ 500$ to cover part of the program costs. Applications were reviewed and participants were notified via email of their acceptance. All students who applied were accepted into the program.

\section{Program Schedule}

Students arrived on campus the Sunday prior to the program start. That evening, they met with each other and student mentors at a Welcome Dinner. Each morning, the students studied math, chemistry, and physics. A faculty member who teaches the freshman level course in that subject taught each class. The academic focus for each course was a review of essential high school material, including pre-calculus, basic chemical reactions, and Newtonian physics, needed for success in the college level course. Students attended evening recitation sections to receive extra help with problem sets, and each course had at least one test to evaluate student learning progress and accustom students to the pressures of college exams.

During the afternoon, the students participated in hands-on design and computer labs to familiarize them with important computer software and increase their comfort with engineering 
design. Specifically, the students learned Matlab, Creo, and Microsoft Excel and Powerpoint. In the first module, they built solar cars. This module was selected because the students expressed interest in alternative energy, and it was an ideal platform to provide students with both hands-on and computational design and building experience. Specifically, the students characterized the solar panels, built an existing solar car design, created their own solar car design, and drew their solar car designs in Creo computer aided design software. They then presented their results to the other student teams. In the second module, the students programmed Lego NXT robots and competed in a Sumobot challenge. This module was selected to prepare the students for a similar module in the freshman design course. The afternoon courses were coordinated and taught by graduate students, who were selected because they were top teaching assistants in the Drexel freshman engineering curriculum. When possible, female and minority students were selected.

In the evenings and during the weekend, the students socialized with current Drexel Engineering faculty and students and participated in social activities to build community and discover opportunities both at the University and in Philadelphia. Department heads and advisors met the students during Introduction to Engineering at the College, the Society of Women Engineers hosted a barbeque, and peer mentors took students to activities throughout the city, including tours and miniature golf. Social activities provided a means for students to interact with each other in a casual, non-competitive way while also experiencing cultural and historical sites and familiarizing themselves with a new area. The program concluded with a celebration at a baseball game. Past participants of the program and members of engineering focused clubs and organizations at the College were often invited to these events as a way to serve as casual mentors for the program participants. See Table 2 for detailed program schedule.

Table 2: 2013 Program Schedule

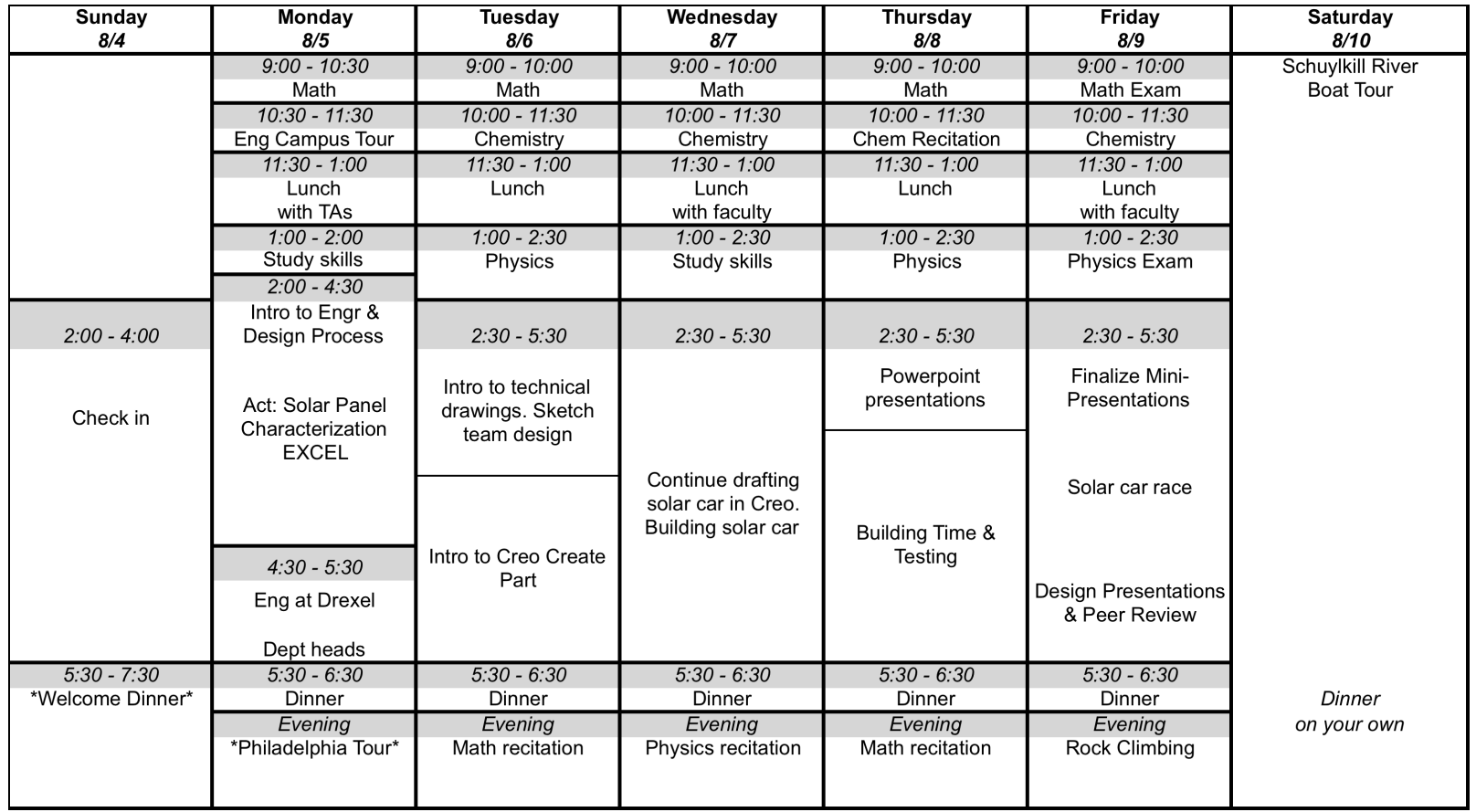




\begin{tabular}{|c|c|c|c|c|c|c|}
\hline $\begin{array}{l}\text { Sunday } \\
8 / 11\end{array}$ & $\begin{array}{l}\text { Monday } \\
8 / 12\end{array}$ & $\begin{array}{l}\text { Tuesday } \\
8 / 13\end{array}$ & $\begin{array}{c}\text { Wednesday } \\
8 / 14\end{array}$ & $\begin{array}{c}\text { Thursday } \\
8 / 15\end{array}$ & $\begin{array}{l}\text { Friday } \\
8 / 16\end{array}$ & $\begin{array}{c}\text { Saturday } \\
8 / 17\end{array}$ \\
\hline \multirow{16}{*}{$\begin{array}{c}\text { Mini-golf } \\
\text { at } \\
\text { Franklin Square }\end{array}$} & $9: 00-10: 00$ & $9: 00-10: 00$ & $9: 00-10: 00$ & $9: 00-10: 00$ & $9: 00-10: 00$ & \multirow[t]{19}{*}{ Depart } \\
\hline & Math & Math & Math & Math Exam & Math & \\
\hline & $10: 00-11: 30$ & $10: 00-11: 30$ & $10: 00-11: 30$ & $10: 00-11: 30$ & $10: 00-11: 30$ & \\
\hline & Chemistry & Chem Recitation & Chemistry & Chem Exam & Chemistry & \\
\hline & $11: 30-1: 00$ & $11: 30-1: 00$ & $11: 30-1: 00$ & $11: 30-1: 00$ & $11: 30-1: 00$ & \\
\hline & $\begin{array}{c}\text { Lunch } \\
\text { with TAs }\end{array}$ & Lunch & $\begin{array}{c}\text { Lunch } \\
\text { with faculty }\end{array}$ & $\begin{array}{c}\text { Lunch } \\
\text { with sponsor }\end{array}$ & $\begin{array}{c}\text { Lunch } \\
\text { with faculty }\end{array}$ & \\
\hline & $1: 00-2: 00$ & \multirow{3}{*}{ Physics } & $1: 00-2: 30$ & $1: 00-2: 30$ & $1: 00-2: 30$ & \\
\hline & Study skills & & \multirow{2}{*}{ Study skills } & \multirow[t]{2}{*}{ Physics Exam } & \multirow[t]{2}{*}{ Physics } & \\
\hline & $2: 00-4: 30$ & & & & & \\
\hline & Introduction to Matlab & $2: 30-5: 30$ & $2: 30-5: 30$ & $2: 30-5: 30$ & $2: 30-4: 30$ & \\
\hline & Worm or Robot & \multirow{4}{*}{$\begin{array}{l}\text { Build Robot with light } \\
\text { sensor }\end{array}$} & \multirow{4}{*}{$\begin{array}{l}\text { Intro to flow diagrams } \\
\text { and closed loops } \\
\text { Draw flow diagram } \\
\text { for robot maneuver } \\
\text { around obstacle } \\
\text { Design Challenge } \\
\text { Rules \& Guidelines }\end{array}$} & \multirow[b]{2}{*}{ Build Sumobots } & Presentations & \\
\hline & $\begin{array}{l}\text { Programming } \\
\text { Challenge }\end{array}$ & & & & $\begin{array}{l}\text { Final Sumobot } \\
\text { Challenge }\end{array}$ & \\
\hline & & & & \multirow{3}{*}{$\begin{array}{c}\text { Preliminary Sumobot } \\
\text { Challenge }\end{array}$} & & \\
\hline & $4: 30-5: 30$ & & & & $4: 30-5: 30$ & \\
\hline & $\begin{array}{l}\text { Eng at Drexel } \\
\text { Student Orgs }\end{array}$ & $\begin{array}{c}\text { Program robots to } \\
\text { trace shapes, follow } \\
\text { line }\end{array}$ & Program Sumobots & & Alumni social & \\
\hline & $6 p m$ & $5: 30-6: 30$ & $5: 30-6: 30$ & $5: 30-6: 30$ & \multirow{4}{*}{$\begin{array}{c}6: 00-10: 00 \\
\text { Farewell Dinner } \\
\text { Camden } \\
\text { Riversharks }\end{array}$} & \\
\hline \multirow{3}{*}{$\begin{array}{c}\text { Dinner } \\
\text { on your own }\end{array}$} & SWE BBQ & Dinner & Dinner & Dinner & & \\
\hline & Evening & Evening & Evening & Evening & & \\
\hline & Free & Physics recitation & Math recitation & Free & & \\
\hline
\end{tabular}

\section{Budget}

The program's corporate sponsors paid for the majority of the program's costs. Program participants paid their transportation to and from the University and also were asked to pay $\$ 500$ to secure their space in the program and demonstrate commitment to attending. Each year approximately $10 \%$ of the participants asked for financial assistance and their $\$ 500$ fee was reduced based on the student's financial aid record. Main costs associated with the program included housing, meals, faculty and TA stipends, and events (Table 3).

Table 3: Program Budget

\begin{tabular}{|l|l|}
\hline Costs & \\
\hline Social Activities & \\
\hline Welcome Dinner & $\$ 900$ \\
\hline Philadelphia Tours & $\$ 1,050$ \\
\hline Rock Climbing & $\$ 150$ \\
\hline Final Event: Baseball Game & $\$ 2,750$ \\
\hline Other Activities & $\$ 600$ \\
\hline & \\
\hline Housing and Meals & \\
\hline Dining Hall & $\$ 5,500$ \\
\hline Housing & $\$ 10,000$ \\
\hline
\end{tabular}




\begin{tabular}{|l|l|}
\hline & \\
\hline Faculty and TA Payment & \\
\hline Faculty & $\$ 10,000$ \\
\hline Teaching Assistants & $\$ 6,000$ \\
\hline & \\
\hline Laboratory Supplies & \\
\hline Solar Cars & $\$ 1,000$ \\
\hline Miscellaneous Supplies & $\$ 500$ \\
\hline & \\
\hline Total Cost & $\$ 38,450$ \\
\hline & \\
\hline Revenues & \\
\hline Corporate Contributions & $\$ 33,000$ \\
\hline Student Payment & $\$ 9,000$ \\
\hline & \\
\hline Total Revenue & $\$ 42,000$ \\
\hline
\end{tabular}

\section{Assessment}

Students were evaluated using quantitative and qualitative data. Students completed surveys based on the National Engineering Students' Learning Outcomes Survey at the start and end of the program. Each year the survey questions varied slightly to reflect unique changes made to the program or new labs that were introduced. Student's grade point averages (GPAs) and retention rates were also used as a form of assessment. The program participants GPAs and retention rates were compared against women and minority non-participants and with College of Engineering students as a whole.

\section{Program Outcomes}

\section{Program Participants}

In year one (2011) 18 students participated in the program. 14 of these were women, and 4 were underrepresented minorities. In year two (2012) 26 students participated in the program; 14 of the participants were women, and 14 were underrepresented minorities. In year three (2013) 22 students participated in the program; 13 of the participants were female, and 13 were underrepresented minorities. Students who declined to participate in the program will be surveyed in the future to determine why some students choose to participate and others do not.

Survey Results 
Each year, students showed significant positive outcomes following the program. In 2011 students showed the largest improvement in evaluating problems and recognizing contemporary issues in the science and technology fields. In addition students also reported strong knowledge and understanding of their post-graduation goals and the steps required to achieve those goals. In 2012, participants felt that the program helped them solve open ended problems, improved their understanding of computational and numerical tools needed to solve programs, and improved their ability to use feedback from an experiment to create improved solutions. In 2013, problem solving, product and system design, and communication showed the highest reported increases. In the post survey, students also wrote general comments about what they liked and disliked about the program. Students felt the program provided them with an accurate "taste of college", made them feel like they "had an advantage over other freshman" through their participation and meeting freshman year professors early, allowed them to "meet new friends", "make connections with upperclassman, TAs and faculty", and "become familiar with campus". Students also indicated the bus tour and other off campus activities were some of the most enjoyable social components. The two main reported dislikes were the "tedious schedule" and "mandatory group activities." Students also comments for program improvement included: more study skills session, less required evening activities, and more breaks throughout the day. All participants indicated that they would recommend the program because they met alumni who could help in the future, made friends, helped review materials for the upcoming year, and learned to be independent.

\section{Grade Point Averages (GPAs)}

Program participants' GPAs were at or above average. Students entering Drexel University College of Engineering in Fall 2011 averaged a 2.89 GPA (+/- 0.77) following their second year. 2011 program participants who were still enrolled at the University at the end of year 2 had a 2.87 GPA (+/- 0.49). A similar pattern holds for 2012. Drexel College of Engineering students entering in Fall 2012 averaged a 2.92 GPA (+/- 0.75) following their first year. 2012 program participants had a 3.05 GPA (+/- 0.63) following their first year (Table 4). These data suggest that program participants' GPAs were the same - and probably higher - than that of Drexel College of Engineering students overall.

Table 4: Drexel College of Engineering Students GPA and Program Participant GPA

\begin{tabular}{|l|l|l|}
\hline & College of Engineering & Program Participants \\
\hline 2011 & $2.89(+/-0.77)$ & $2.87(+/-0.49)$ \\
\hline 2012 & $2.92(+/-0.75)$ & $3.05(+/-0.63)$ \\
\hline
\end{tabular}

\section{Retention}

Program participant retention was also higher than the average. The Drexel College of Engineering retention rate is $76.8 \%$ from freshman to sophomore year and $68.3 \%$ from freshman to pre-junior $\left(3^{\text {rd }}\right)$ year. For female and underrepresented minority students who were offered acceptance to the program but did not participate, the retention rate was $78.5 \%$ from freshman to sophomore year and $62.1 \%$ from sophomore to pre-junior $\left(3^{\text {rd }}\right)$ year. Program participant retention was $92 \%$ after year one and $83 \%$ after year two (Table 5). This indicates that the 
students in the program were more likely to stay at the University and in the College of Engineering compared to their counterparts and the college population overall. While the specific reasons for increased retention are unknown, we believe that increased academic preparation coupled with peer mentorship provided the program participants skills, knowledge and support that aided in their persistence.

Table 5: Retention Rates for College of Engineering Students, All Women and Underrepresented Minorities, and Program Participants

\begin{tabular}{|l|l|l|l|}
\hline & $\begin{array}{l}\text { College of } \\
\text { Engineering }\end{array}$ & All Women and Minorities & Program Participants \\
\hline 2011 & $68.3 \%$ & $62.1 \%$ & $83.0 \%$ \\
\hline 2012 & $76.8 \%$ & $78.5 \%$ & $92.0 \%$ \\
\hline
\end{tabular}

\section{Conclusion}

In conclusion, the Drexel College of Engineering Summer Diversity Program aimed to provide incoming female and underrepresented minority freshmen with the academic and social foundation to help them succeed in their engineering education. Student survey responses indicate that the program was successful at improving individual skills such as problem solving. Retention rates for program participants were higher than non-program participants as well as higher than College of Engineering students as a whole and this is especially noteworthy from sophomore to pre-junior year. Although there are other variables to consider, these data indicate that the two-week Summer Diversity Program may have provided students with an academic and social advantage that has helped them to succeed at Drexel University.

\section{References}

1. National Science Foundation, National Center for Science and Engineering Statistics (2013) Women, Minorities, and Persons with Disabilities in Science and Engineering: 2013. Special Report NSF 13-304. Arlington, VA. Available at http://www.nsf.gov/statistics/wmpd/.

2. Hill, C., Corbett, C., \& St. Rose, A. (2010). Why so few? Women in science, technology, engineering, and mathematics. AAUW. Washington, D.C.

3. Eccles, J. S. (2007). Where Are All the Women? Gender Differences in Participation in Physical Science and Engineering. In S. J. Ceci, W. M. Williams (Eds.), Why aren't more women in science?: Top researchers debate the evidence (pp. 199-210). American Psychological Association.

4. Reichert, M., \& Absher, M. (1997). Taking another look at educating African American engineers: The importance of undergraduate retention. Journal of Engineering Education, 86(3), 241-253.

5. Murphy, T., Gaughan, M., Hume, R., \& Gordon Moore Jr., S. (2010). College graduation rates for minority students in a selective technical university: Will participation in a summer program contribute to success? Educational Evaluation and Policy Analysis, 32: 70-83.

6. Chen, X., \& Thomas, W. (2009). Students who study science, technology, engineering and mathematics (STEM) in post-secondary education. NCES 2009-161. Washington, D.C.: U.S. Department of Education, National Center for Education Statistics.

7. Beasley, M. \& Fischer, M. (2012). Why they leave: The impact of stereotype threat on the attrition of women and minorities from science, math and engineering majors. Social Psychology of Education, 15(4), 427-448.

8. Darling-Hammond, L. (2004). The color line in American education; Race, resources, and student 
achievement. Du Bois Review: Social Science Research on Race, 1(2), 213-246.

9. May, G. S., \& Chubin, D. E. (2003). A retrospective on undergraduate engineering success for underrepresented minority students. Journal of Engineering Education, 92(1), 27-39.

10. Astin, A. (1985, July/August). Involvement: The cornerstone of excellence. Change.

11. Pascarella, E. T., \& Terenzini, P. T. (1991). How college affects students: Findings and insights from twenty years of research. San Francisco: Jossey-Bass.

12. Trippi, J., \& Cheatham, H. E. (1991). Counseling effects on African American college students' graduation. Journal of College Student Development, 32(4), 342-349.

13. Sanchez, A. R., \& King, M. (1986). Mexican Americans' use of counseling services: Cultural and institutional factors. Journal of College Student Personnel, 27(4), 344-349.

14. Gleghorn, V. \& Stwakkey, C. Impact of Transition Programs on the Retention of Underrepresented Minority Students . ASEE Annual Conference Proceeding. Washington, DC: American Society for Engineering Education, 2011.

15. National Academy of Sciences (US), National Academy of Engineering (US), and Institute of Medicine (US) Committee on Underrepresented Groups and the Expansion of the Science and Engineering Workforce Pipeline. (2011). Expanding underrepresented minority participation. Washington, D.C.: National Academies Press. 